\title{
Clinical decision rules for acute bacterial meningitis: current insights
}

\author{
This article was published in the following Dove Press journal: \\ Open Access Emergency Medicine \\ 19 April 2016 \\ Number of times this article has been viewed
}

\author{
Alain Viallon' \\ Elisabeth Botelho-Nevers ${ }^{2}$ \\ Fabrice Zeni ${ }^{3}$ \\ 'Emergency Department, 'Department \\ of Infectious Disease, ${ }^{3}$ Intensive \\ Care Unit, University Hospital, Saint- \\ Etienne, France
}

\begin{abstract}
Acute community-acquired bacterial meningitis (BM) requires rapid diagnosis so that suitable treatment can be instituted within 60 minutes of admitting the patient. The cornerstone of diagnostic examination is lumbar puncture, which enables microbiological analysis and determination of the cerebrospinal fluid (CSF) cytochemical characteristics. However, microbiological testing is not sufficiently sensitive to rule out this diagnosis. With regard to the analysis of standard CSF cytochemical characteristics (polymorphonuclear count, CSF glucose and protein concentration, and CSF:serum glucose), this is often misleading. Indeed, the relatively imprecise nature of the cutoff values for these BM diagnosis markers can make their interpretation difficult. However, there are two markers that appear to be more efficient than the standard ones: CSF lactate and serum procalcitonin levels. Scores and predictive models are also available; however, they only define a clinical probability, and in addition, their use calls for prior validation on the population in which they are used. In this article, we review current methods of BM diagnosis.
\end{abstract}

Keywords: meningitis, diagnosis, emergency

\section{Introduction}

With an incidence of $\sim 1-2 / 100,000$ inhabitants in developed countries and an estimated mortality of $10 \%-20 \%,{ }^{1,2}$ bacterial meningitis (BM) requires urgent diagnosis so that treatment can be initiated as early as possible. This diagnosis, postulated on the basis of clinical presentation, hinges on cerebrospinal fluid (CSF) analysis. In some cases, where there is purulent CSF, the associated clinical presentation may be sufficient grounds for initiating treatment, but most of the times the results of the CSF parameters are required. This diagnostic challenge is compounded by the fact that BM must be differentiated from viral meningitis (VM). These two entities can assume similar characteristics.

Of necessity, an emergency diagnosis can only be based on parameters that can be determined routinely, within a short period of time and by a reproducible method.

\section{Clinical parameters}

The clinical presentation varies according to several factors: age, duration of evolution of symptoms at the time of clinical examination, presence of underlying diseases, and microorganism involved. ${ }^{3}$ The classic triad of fever/neck stiffness/altered mental status or headache, although partially or fully present in $50 \%-95 \%$ of cases (with at least two signs), has only $40 \%-50 \%$ sensitivity in BM diagnosis. Attia et al analyzed
Correspondence: Alain Viallon Emergency Department, HôpitalNord, 42055 Saint Etienne, Cedex 2, France Tel +33477I 20587 Email alain.viallon@chuse.fr
Open Access Emergency Medicine 2016:8 7-16

(c) (5) $\odot 2016$ Viallon et al. This work is published and licensed by Dove Medical Press Limited. The full terms of this license are available at https://www.dovepress.com/terms. (c) you hereby accept the Terms. Non-commercial uses of the work are permitted without any further permission from Dove Medical Press Limited, provided the work is properly attributed. For you hereby accept the Terms. Non-commercial uses of the work are permitted without any further permission from Dove Medical
permmercial use of this work, please see paragraphs 4.2 and 5 of our Terms (https://www.dovepress.com/terms.php). 
the sensitivity of these symptoms for BM diagnosis after selecting ten studies out of 139 combining 845 meningitis episodes (including 66 cases of aseptic meningitis [AM] and seven tuberculous meningitis). ${ }^{4}$ The sensitivity of this triad for BM diagnosis was only 46\% (95\% CI 22-69). In a prospective study conducted between 1998 and 2002, out of 696 BM episodes, this sensitivity was only $44 \% .^{2}$ Other studies produced similar results. ${ }^{5-7}$ Other indications, such as signs of intracranial hypertension, neurologic deficit syndrome, and skin rash, are less common and less useful for diagnosing BM. ${ }^{2,4-6}$ In the elderly population, confusion may be at the forefront. ${ }^{7,8}$ Considering more specifically the clinical presentation in children, several findings can be ascertained..$^{9-11}$ In new-born babies, bulging fontanelle and seizure were found in $30 \%-40 \%$ of cases of BM, whereas in children aged 2-4, fever and stiff neck featured among $70 \%-74 \%$ of cases.

As soon as there is a clinical suspicion of meningitis, lumbar puncture is imperative. Its most serious complication (brain herniation) arises in $<5 \%$ of cases. ${ }^{6}$ Meningitis itself, or one of its complications (brain abscess, obstructive hydrocephalus, etc), can predipose to this event. To limit this risk, a brain scan may be performed before the lumbar puncture in a population of identified patients (neurologic deficit, seizure, immunocompromised, history of brain injury, Glasgow score $<11$, and known mass lesion). ${ }^{6,12}$ However, the imaging procedure should not delay antibiotic therapy. In fact, it is highly probable that deferring the administration of antibiotherapy increases mortality. ${ }^{13,14}$ This was confirmed by a recent retrospective study, which showed that mortality increased by $13 \%$ for every hour without antibiotics. ${ }^{15}$ Furthermore, Swedish guidelines no longer advocate performing a prelumbar puncture CT scan in patients with altered mental status, but the issue remains controversial. ${ }^{16-18}$ In children, there are no specific studies pertaining to the incidence of herniation following lumbar puncture, which remains scarce in children. ${ }^{19}$ Moreover, a normal cerebral computerized tomography cannot rule out brain herniation due to rapid peak variation in the increase in intracranial pressure.

The objective of this study was to clearly administer antibiotherapy within 30-60 minutes of the patient being admitted. Other indirect arguments call for the rapidity of administration of the antibiotic therapy and relate to the duration of sterilization of the CSF after starting the antibiotic therapy. On the one hand, we are aware that prior antibiotic therapy per os is responsible for an increased number of patients with BM and CSF examination showing no bacteria. On the other hand, Kanegaye et al have demonstrated (in children) that sterilization could be obtained with parenteral antibiotic therapy adapted to the bacteria in 2 hours (nine cases of Neisseria meningitidis) ${ }^{20}$ In the case of meningitis with Streptococcus pneumoniae, this is obtained within $4-9$ hours in $100 \%$ of patients.

\section{Bacteriological and cytological parameters of CSF}

The first stage in CSF interpretation is its macroscopic appearance. In fact, a fluid of purulent appearance is sufficient grounds for initiating empirical antibiotherapy before the fluid results are available.

The only bacteriological parameter compatible with deferring the institution of treatment is direct examination of the CSF (Gram's stain) and the detection of bacterial antigens by latex agglutination. However, direct examination may not be informative in $20 \%-40 \%$ of cases. ${ }^{2,21}$ This depends on the bacterial inoculum of the CSF and the type of bacterium. Direct examination is all the more informative in the presence of S. pneumoniae or Haemophilus influenzae than Listeria monocytogenes or gram negative bacilli. The incidence of this bacterium is obviously age related.

With regard to bacterial antigen screening, its result does not seem to affect the decision to institute antibiotherapy where BM is suspected. ${ }^{22}$ Rapid detection of the bacterial genome by multiplex polymerase chain reaction testing can be performed in $<2$ hours and can detect the main pathogens encountered in this situation. This form of testing has good sensitivity and specificity, in the region of $90 \%-100 \%$, but it remains underused as a routine method, and its contribution to the emergency diagnosis of BM should be clarified. As for blood cultures, these should be performed systematically; however, it takes 12-24 hours to obtain the first results.

With regard to the cytological parameters, high pleocytosis $\left(>100\right.$ cells $\left./ \mathrm{mm}^{3}\right)$ associated with predominant polynuclear neutrophils $(>80 \%)$ is a standard finding. However, these parameters are often misleading, with an absence of pleocytosis (10\% of cases) or predominant polynuclears. This is seen in the van de Beek et al set, where out of 645 patients with BM, 47 (7\%) patients did not have pleocytosis. ${ }^{2}$ In the Durand set, which included 296 patients with BM, 10\% did not have pleocytosis, and 20\% did not have predominant polynuclears. ${ }^{5}$ Furthermore, these two parameters have low discriminatory power between BM and VM. This is shown in the study by Spanos et al, where 205 episodes of VM were compared to 217 episodes of BM, and CSF with predominant polynuclears was identified in only $40 \%{ }^{23}$ The polynuclear discrimination threshold between 
VM and BM was 1,180, but with a major overlap between the two groups in the median number (interquartile [IQ]) of leukocytes $/ \mathrm{mm}^{3}$ in CSF (VM 100 IQ [37-250] and BM 1,195 [330-4,400]). Finally, in different published series of strictly pediatric populations, no pleyocytosis was found in $\sim 15 \%$ of patients with BM. ${ }^{24,25}$

\section{Standard clinical parameters of CSF} Protein CSF concentration

CSF protein concentration increases in BM, with average levels between $1 \mathrm{~g} / \mathrm{L}$ and $5 \mathrm{~g} / \mathrm{L} .^{2,5,12,26-30}$ The sensitivity (Se) and specificity (Sp) of this marker (Table 1) for the diagnosis of BM were examined for thresholds ranging from $0.5 \mathrm{~g} / \mathrm{L}$ to $2 \mathrm{~g} / \mathrm{L}$. The Se values varied from $60 \%$ to $86 \%$ and from $60 \%$ to $100 \%$ for the Sp. In the study by Viallon et al, which used receiver operating characteristics (ROC) curves to compare the discriminatory power of the various biochemical parameters of CSF, CSF protein concentration was one of the least relevant markers. ${ }^{29}$ In this prospective study, 32 patients had BM, 90 had VM, and 57 patients were in the control group. At the $1.88 \mathrm{~g} / \mathrm{L}$ threshold, Se and Sp for BM diagnosis were $84 \%$ and $91 \%$, respectively.

Finally, in the various sets, $1 \%-10 \%$ of patients with BM had normal CSF protein concentration, while for $\sim 5 \%-25 \%$ of patients with VM, this level was $>1 \mathrm{~g} / \mathrm{L}$.

\section{CSF glucose and CSF:serum glucose}

The normal glucose level in CSF varies from $2.6 \mathrm{mmol} / \mathrm{L}$ to $4.2 \mathrm{mmol} / \mathrm{L}$ and for glycemia between $3.9 \mathrm{mmol} / \mathrm{L}$ and $6.7 \mathrm{mmol} / \mathrm{L}$, that is, a CSF:serum glucose ratio in the region of 0.6. When BM is present, the CSF glucose level falls $<2.5 \mathrm{mmol} / \mathrm{L}$ with a CSF:serum ratio of $<0.4$. Average levels described in BM sets in the literature for these two parameters are in the region of $1-2 \mathrm{mmol} / \mathrm{L}$ for CSF glucose and 0.2-0.4 mmol/L for its CSF:serum ratio (Table 2)., ${ }^{2,5,21,26-31}$

However, the CSF glucose level performance remains inadequate for diagnosing BM. For example, in the study by Durand et al, only $50 \%$ of patients had a CSF glucose level of $<2.2 \mathrm{mmol} / \mathrm{L} .^{5}$ Furthermore, other BM sets have demonstrated the normality of this parameter in $25 \%-40 \%$ of patients. ${ }^{23,30}$ With a threshold of $<0.4$, the CSF:serum glucose ratio appears to be more discriminatory for diagnosing BM than CSF glucose..$^{28-30,33-35}$ This superiority was clearly demonstrated in the study by Viallon et al by comparing the ROC curves of these two parameters. ${ }^{29}$ Data published relating to children have shown similar results. ${ }^{31,32}$

For this marker, it is preferable to select, as an indicator of BM, a threshold of $<0.4$ for the CSF:serum glucose ratio rather than CSF glucose. Where there is associated hyperglycemia, it is preferable to select the absolute value of CSF glucose with a threshold of $<2.2 \mathrm{mmol} / \mathrm{L}$.

\section{CSF lactate}

One of the first publications on the use of lactates as a BM marker seems to date from $1933 .{ }^{36}$ The normal level of lactates in the blood and in CSF is $<2 \mathrm{mmol} / \mathrm{L}$, and CSF lactate concentrations are not influenced by those of serum. ${ }^{35,37}$ Furthermore, this assay takes only a few minutes and is inexpensive.

Two meta-analyses, published in 2010 and 2011, highlighted the usefulness of CSF lactate in the diagnosis of BM in adults and children. ${ }^{38,39}$ These two studies determined the diagnostic power of CSF lactate and serum in BM and their discriminatory power between BM and VM. The Huy et al meta-analysis combined 25 studies involving 1,692 patients (783 with BM and 909 with VM), while the Sakushima

Table I Cerebrospinal fluid protein concentration values for differentiating bacterial and viral or aseptic meningitis

\begin{tabular}{|c|c|c|c|c|c|c|c|c|}
\hline References & Study methods & Years & Comparison & Number & $\begin{array}{l}\text { Cutoff } \\
\text { value }\end{array}$ & $\begin{array}{l}\text { Determination } \\
\text { of cutoff }\end{array}$ & $\begin{array}{l}\mathrm{Se} \\
(\%)\end{array}$ & $\begin{array}{l}\text { Sp } \\
(\%)\end{array}$ \\
\hline Donald and Malan ${ }^{26}$ & Prospective, P/A & - & $\mathrm{BM} / \mathrm{AM} / \mathrm{C}$ & $95 / 73 / 273$ & $\geq \mathrm{Ig} / \mathrm{L}$ & Empirical & 81.5 & 98.4 \\
\hline \multirow[t]{2}{*}{ White et $\mathrm{al}^{33}$} & Retrospective & 13 years & $\mathrm{BM} / \mathrm{VM}$ & $23 / 45$ & $\geq 0.6 \mathrm{~g} / \mathrm{L}$ & Empirical & 95.5 & 55.6 \\
\hline & & & $\mathrm{BM} / \mathrm{C}$ & $23 / 2,207$ & $\geq 0.6 \mathrm{~g} / \mathrm{L}$ & Empirical & 95.5 & 83.6 \\
\hline Spanos et $\mathrm{al}^{23}$ & Retrospective, P/A & 1989-1980 & $\mathrm{BM} / \mathrm{VM}$ & $217 / 205$ & $\geq 2.2 \mathrm{~g} / \mathrm{L}$ & $\begin{array}{l}\text { Somers' D rank } \\
\text { correlation }\end{array}$ & - & - \\
\hline Genton and Berger ${ }^{27}$ & Retrospective, A & |977-1983 & $\mathrm{BM} / \mathrm{VM}$ & $21 / 25$ & $\geq 2 \mathrm{~g} / \mathrm{L}$ & Empirical & 86.0 & 100.0 \\
\hline \multirow[t]{2}{*}{ Lindquist et $\mathrm{al}^{28}$} & Prospective, P/A & 1982-1985 & $\mathrm{BM} / \mathrm{VM} / \mathrm{CNS}$ & $79 / 218 / 37$ & $\geq \mathrm{I} g / \mathrm{L}$ & Empirical & 69 & 90 \\
\hline & & & & & $\geq 1.5 \mathrm{~g} / \mathrm{L}$ & Empirical & 55 & 98 \\
\hline Viallon et $\mathrm{al}^{29}$ & Prospective, A & 1997-1999 & $\mathrm{BM} / \mathrm{VM} / \mathrm{C}$ & $32 / 90 / 57$ & $\geq 1.88 \mathrm{~g} / \mathrm{L}$ & Youden's index & 84.0 & 91.0 \\
\hline Viallon et $\mathrm{al}^{21}$ & Prospective, A & 1997-2009 & $\mathrm{BMN} / \mathrm{VM}$ & $35 / 218$ & $\geq 1.88 \mathrm{~g} / \mathrm{L}$ & Youden's index & 89.0 & 93.0 \\
\hline Tamune and Takeya ${ }^{34}$ & Retrospective, A & $2007-2012$ & $\mathrm{BM} / \mathrm{AM}$ & $15 / 129$ & $\geq \mathrm{Ig} / \mathrm{L}$ & Youden's index & 86.7 & 76.9 \\
\hline
\end{tabular}

Abbreviations: A, adults; AM, aseptic meningitis; BM, bacterial meningitis; BMN, BM with no bacteria on Gram's stain; C, control; CNS, other central nervous infection than BM; E, encephalitis; P, pediatrics; Se, sensitivity; Sp, specificity; VM, viral meningitis; - , unknown. 
Table 2 CSF glucose concentration and CSF serum glucose ratio values for differentiating bacterial and viral or aseptic meningitis

\begin{tabular}{|c|c|c|c|c|c|c|c|c|}
\hline \multirow[t]{2}{*}{ References } & \multicolumn{4}{|c|}{ CSF/ glucose concentration ( $\mathrm{mmol} / \mathrm{L})$} & \multicolumn{4}{|c|}{ CSF/serum glucose ratio } \\
\hline & Cutoff value & $\begin{array}{l}\text { Method of } \\
\text { determination }\end{array}$ & Se (\%) & Sp (\%) & $\begin{array}{l}\text { Cutoff } \\
\text { value }\end{array}$ & $\begin{array}{l}\text { Method of } \\
\text { determination }\end{array}$ & Se $(\%)$ & Sp (\%) \\
\hline Donald and Malan ${ }^{26}$ & $<2.2 \mathrm{mmol} / \mathrm{L}$ & Empirical & 76.3 & 99 & - & - & - & - \\
\hline Spanos et $\mathrm{al}^{23}$ & $<1.9 \mathrm{mmol} / \mathrm{L}$ & $\begin{array}{l}\text { Somers' D rank } \\
\text { correlation }\end{array}$ & - & - & 0.23 & - & - & - \\
\hline Genton and Berger ${ }^{27}$ & - & - & - & - & 0.4 & Empirical & 91 & 96 \\
\hline \multirow[t]{2}{*}{ Lindquist et $\mathrm{al}^{28}$} & $<2.2$ & Empirical & 53 & 98 & $<0.5$ & Empirical & 81 & 84 \\
\hline & & & & & $<0.4$ & Empirical & 70 & 96 \\
\hline Viallon et $\mathrm{al}^{29}$ & $\leq 2.5$ & Youden's index & 99 & 56 & $\leq 0.43$ & Youden's index & 93 & 69 \\
\hline Viallon et $\mathrm{al}^{21}$ & $\leq 2.2$ & Youden's index & 97 & 49 & 0.48 & Youden's index & 84 & 89 \\
\hline Tamune and Takeya ${ }^{34}$ & $\leq 2.2$ & Youden's index & 80 & 92.3 & 0.36 & Youden's index & 92.9 & 92.9 \\
\hline
\end{tabular}

Abbreviations: CSF, cerebrospinal fluid; Se, sensitivity; Sp, specificity; - , unknown.

et al meta-analysis comprised 33 studies with a combined total of 1,985 patients (934 BM and $951 \mathrm{VM}$ ). These two meta-analyses had 22 studies in common. The results of these two meta-analyses were consistent. They demonstrated the superiority of CSF lactate vs classic parameters (CSF leukocytes/count, CSF glucose, and protein concentration) for BM diagnosis with 96\% (95\% CI 95-98) and 93\% (95\% IC 89-96) sensitivity and 94\% (95\% CI 93-96) and 96\% (95\% IC 93-98) specificity. The CSF lactate discriminatory threshold was between $3.7 \mathrm{mmol} / \mathrm{L}$ and $4 \mathrm{mmol} / \mathrm{L}$, at the threshold of $3.9 \mathrm{mmol} / \mathrm{L}$ (determined by Youden's index).

Two other studies published after 2009 yielded similar findings. For Viallon et al, who studied the discriminatory power of CSF lactate in a set of 35 patients with BM and 218 with VM, this parameter performed better than the classic parameters. ${ }^{21}$ Giulieri et al obtained similar results by comparing a group of 18 patients with BM and 27 with VM. ${ }^{40}$ In both studies, the decision-making thresholds of the different parameters were calculated at the maximum Youden's index. For BM diagnosis, this threshold was $3.8 \mathrm{mmol} / \mathrm{L}$ (area under the curve 96\% [95\% CI 0.95-1], Se 94\%, and Sp 97\%) for Viallon et al, it was $3.5 \mathrm{mmol} / \mathrm{L}$ (area under the curve $100 \%$ [95\% CI 1-1], Se 100\%, and Sp 100\%) for Giulieri et al in each of the VM groups in both of these studies; the highest CSF lactate values in the VM group for these two studies were $3.7 \mathrm{mmol} / \mathrm{L}$ and $2.9 \mathrm{mmol} / \mathrm{L} .{ }^{21,40}$ These data confirm the usefulness of CSF lactate for BM diagnosis, with a decisionmaking threshold of $>3.8 \mathrm{mmol} / \mathrm{L}$. It should be noted that the CSF:serum lactate ratio was only of marginal usefulness.

\section{Serum parameters}

\section{Serum C-reactive protein}

In the early phase of inflammation, serum levels of this protein increase at around the sixth hour after the inflammatory reaction trigger, reaching their peak concentration at around the 48th hour.
In $\mathrm{BM}$, serum C-reactive protein (CRP) levels were described as significantly higher in patients with VM. However, the methods of selecting the decision-making threshold for discriminating between BM and VM cases were diverse, indicating a certain heterogeneity in the literature results.

We shall refer to two studies that set an arbitrary threshold, and two that set a threshold using the ROC curve method.

Hansson et al compared two groups of patients, 60 with BM and 146 with VM. ${ }^{41}$ An arbitrary threshold of $50 \mathrm{mg} / \mathrm{L}$ was selected, yielding Se of $88 \%$ and $\mathrm{Sp}$ of $90 \%$ for BM diagnosis. In a similar study $(\mathrm{BM}=19$ and $\mathrm{VM}=30)$, at the $50 \mathrm{mg} / \mathrm{L}$ threshold, the $\mathrm{Se}$ and $\mathrm{Sp}$ of this marker for $\mathrm{BM}$ diagnosis were $94 \%$ and $70 \%$, respectively. ${ }^{42}$

Three other studies selected their decision-making threshold on the basis of achieving the best Se/Sp duo..$^{29,43,44}$ At the $40 \mathrm{mg} / \mathrm{L}$ threshold, out of $30 \mathrm{BM}$ and $30 \mathrm{VM}$ cases, Paradowski et al identified an Se of $83 \%$ and an Sp of $100 \%$. In the study by Viallon et al, this threshold was identical, with an Se of $84 \%$ and Sp of $90 \%$ for BM diagnosis. ${ }^{29}$ For Morales Casado et al, with a level of $\geq 90 \mathrm{mg} / \mathrm{L}$, CRP has an Se of $67.5 \%$ and an $\mathrm{Sp}$ of $86.3 \%$ for BM diagnosis (BM $=38$ and $\mathrm{VM}=33$ ). ${ }^{44}$

In 1998, Guerdes et al published a meta-analysis that sought to evaluate the diagnostic usefulness of CRP in BM. ${ }^{45}$ Out of 35 selected studies, 14 concerned with serum CRP. The authors emphasized the heterogeneity of populations, methods, CRP assay, and choice of decision-making threshold for this BM diagnosis marker (between $19 \mathrm{mg} / \mathrm{L}$ and $100 \mathrm{mg} / \mathrm{L}$ ). Despite the results published by the authors, this study did not clarify the contribution of serum CRP to $\mathrm{BM}$ diagnosis. This absence of precision was highlighted in the article by Brouwer et al. ${ }^{17}$

\section{Serum procalcitonin}

Procalcitonin (PCT) is a prohormone that is undetectable in healthy subjects but rises rapidly (3-6 hours) after exposure 
to a proinflammatory substance of bacterial origin, to reach a peak at around the eighth hour, subsequently maintaining a plateau phase for the next 24 hours. ${ }^{46}$ The more severe the infection, the higher the peak. Its detection limit is $<0.1 \mathrm{ng} / \mathrm{mL}$, and it is considered to be associated with a bacterial infection when the level rises $>0.5 \mathrm{ng} / \mathrm{mL}$. It was described as associated with bacterial infections in children in 1993, then with BM in children and adults. ${ }^{47-50}$

More studies described the PCT values (Table 3). In 1997, Gendrel et al published a series of 59 patients aged from 3 months to 13 years presenting meningitis, 18 of which (30\%) had BM and $41 \mathrm{VM} .{ }^{48}$ Of the parameters studied (CSF cells, CSF protein, and CRP level), only the PCT was able to differentiate BM and VM in $100 \%$ of the cases. This differentiation was achieved at the threshold of $1.8 \mathrm{ng} / \mathrm{mL}$. In 2008, Dubos et al published a similar study on 180 patients aged from 29 days to 18 years, 96 of which (48\%) had BM and AM in 102 patients. ${ }^{32}$ At the threshold of $0.5 \mathrm{ng} / \mathrm{mL}$, the PCT was able to differentiate BM from AM in $100 \%$ of the cases with sensitivity of $99 \%$ (95\% CI 97-100) and specificity of $83 \%(95 \%$ CI 76-90).

The first study in adults with BM examined the discriminatory power of serum PCT in 23 patients with BM and 57 with VM. ${ }^{49}$ It was possible to discriminate between $\mathrm{BM}$ and $\mathrm{VM}$ in $100 \%$ of cases with a level $<0.22 \mathrm{ng} / \mathrm{mL}$, while all VM cases had a level $<0.15 \mathrm{ng} / \mathrm{mL}$. However, the choice of threshold was arbitrary, and two patients had PCT levels of $<0.5 \mathrm{ng} / \mathrm{mL}$. These two patients had a negative direct examination, as well as negative bacterial cultures, and had received antibiotherapy prior to admission. In 2000, the same team published a set of 32 patients with BM (84\% of cases confirmed by bacterial testing of $\mathrm{CSF}$ ) and 90 with VM. ${ }^{29}$ None had received prior antibiotherapy $>24$ hours prior to admission to accident and emergency department, and none of them had any other sources of infection associated with BM. At the $0.93 \mathrm{ng} /$ $\mathrm{mL}$ threshold, serum PCT discriminated BM from VM in $100 \%$ of cases. The comparison of ROC curves identified the following two best markers for BM diagnosis: serum PCT and CSF lactates.

Other studies on this subject have since been published (Table 3). ${ }^{51-58}$ Clearly, the diagnostic precision of serum PCT for identifying BM depends on the population selected and the method of selecting the marker threshold. In these varied studies, this precision is impaired in the case of atypical germ-induced meningitis (Borrelia burgdorferi and Mycobacterium tuberculosis), nosocomial meningitis, or prior antibiotherapy. Furthermore, some cases of typical community-acquired BM with serum levels of PCT $<0.5 \mathrm{ng} / \mathrm{mL}$ have been described. With a serum level of between $0.5 \mathrm{ng} / \mathrm{mL}$ and $1 \mathrm{ng} / \mathrm{mL}$, serum PCT remains one of the most discriminatory parameters between BM and VM. A recent meta-analysis involving a total of nine studies and 725 patients (192 BM and 533 $\mathrm{VM}$ ) confirms this strong discriminatory power of PCT, with sensitivity of 90\% (95\% CI 84-94) and specificity of 98\% (95\% CI 97-99). ${ }^{59}$ However, there have been no studies with sufficient impact on the prescription of emergency antibiotherapy based on the serum PCT level during BM.

Finally, it should be pointed out that PCT $(B \cdot R \cdot A \cdot H \cdot M \cdot S \cdot$ KRYPTOR system) costs $\sim 21$, whereas CRP costs $\sim € 3$.

Table 3 Serum procalcitonin concentration $(\mathrm{ng} / \mathrm{mL})$ values for diagnosis of bacterial meningitis

\begin{tabular}{|c|c|c|c|c|c|c|c|}
\hline References & Study methods & Comparison & $\begin{array}{l}\text { Number of } \\
\text { patients }\end{array}$ & $\begin{array}{l}\text { Cutoff value } \\
\text { (ng/mL) }\end{array}$ & $\begin{array}{l}\text { Determination } \\
\text { of cutoff }\end{array}$ & Se (\%) & Sp (\%) \\
\hline Gendrel et al, ${ }^{48} 1997$ & Prospective, A/P & $\mathrm{BM} / \mathrm{VM}$ & $|8 / 4|$ & $>5$ & Empirical & 94 & 100 \\
\hline Viallon et $\mathrm{al}^{49} 1999$ & Prospective, A & $\mathrm{BM} / \mathrm{VM} / \mathrm{C}$ & $23 / 57 / 25$ & $\geq 0.2$ & Empirical & 100 & 100 \\
\hline Schwarz et al,,$^{50} 2000$ & Prospective, A & $\mathrm{BM} / \mathrm{VM}+\mathrm{E}$ & $16 / 14$ & $>0.5$ & Empirical & 69 & 100 \\
\hline Viallon et al, ${ }^{29} 2000$ & Prospective, A & $\mathrm{BM} / \mathrm{VM}$ & $32 / 90$ & $\geq 0.93$ & Youden's index & 100 & 100 \\
\hline Hoffmann et al, ${ }^{51} 200 \mathrm{I}$ & Prospective, A & BMO & 12 & Range $0.13->100$ & - & - & - \\
\hline Jereb et al, ${ }^{52} 200 \mathrm{I}$ & Prospective, A & $\mathrm{BM} / \mathrm{E}$ & $20 / 25$ & $\geq 0.5$ & Empirical & 90 & 100 \\
\hline Ray et al, ${ }^{53} 2007$ & Prospective, A & $\mathrm{BM} / \mathrm{VM}$ & $18 / 133$ & $\geq 2.13$ & Youden's index & 87 & 100 \\
\hline Onal et al, ${ }^{54} 2008$ & Prospective, $\mathrm{P}$ & $\mathrm{BM} / \mathrm{VM}$ & $16 / 14$ & $\geq 0.5$ & Empirical & 93.7 & 100 \\
\hline Dubos et al, 2008 & Prospective, $\mathrm{P}$ & BM/AM & $96 / 102$ & $\geq 0.5$ & Empirical & 99 & 83 \\
\hline Makoo et al, ${ }^{55} 2010$ & Prospective, A & BM/AM & $19 / 3 \mid$ & $\geq 0.5$ & Empirical & 100 & 87.9 \\
\hline Viallon et al, ${ }^{21} 201 \mathrm{I}$ & Prospective, A & $\mathrm{BM} / \mathrm{VM}$ & $35 / 218$ & $\geq 0.28$ & Youden's index & 97 & 100 \\
\hline Abdelkader et al, ${ }^{56} 2014$ & Prospective, $\mathrm{A}$ & BM/AM & $16 / 24$ & $\geq 1.2$ & Youden's index & 68.8 & 83.3 \\
\hline Konstantinidis et $\mathrm{al},{ }^{57} 2015$ & Prospective, A/P & BM/AM & $19 / 11$ & $>0.5$ & Empirical & 100 & 96.4 \\
\hline Shen et al, ${ }^{58} 2015$ & Prospective, A & $\mathrm{BM} / \mathrm{AM}$ & $45 / 75$ & $\geq 0.88$ & Youden's index & 87 & 100 \\
\hline
\end{tabular}

Abbreviations: A, adults; AM, aseptic meningitis; BM, bacterial meningitis; BMO, other site infection associated to BM; C, control; CNS, central nervous infection other than BM; E, encephalitis; P, pediatrics; Se, sensitivity; Sp, specificity; VM, viral meningitis; - , unknown. 


\section{Values of these parameters in the presence of a non contributory direct examination of the CSF}

These parameters take on their full importance in this situation: generally, the CSF is clear or slightly cloudy with no bacterial yield on Gram's stain, which is sometimes associated with prior antibiotic treatment.

Few studies have focused specifically on this group of patients. ${ }^{21,23,53}$ Spanos et al compared the data of $134 \mathrm{BM}$ patients with a useful direct examination of $\mathrm{CSF}(\mathrm{BM}+)$ with 55 patients for whom direct examination of CSF did not yield any information (BM-). ${ }^{23}$ The median values (IQ range) of markers were described and compared in the $\mathrm{BM}+$ group vs the BM-group. Protein concentrations in CSF were $1.80 \mathrm{~g} / \mathrm{L}$ (1.18-3.04) vs $1.28(0.8-2.5), P=0.02$. The CSF glucose was $1.70 \mathrm{mmol} / \mathrm{L}(0.8-2.8)$ vs $3.4(1.4-4.5), P<0.001$. With regard to the CSF:serum glucose ratio, it was $0.23(0.12-0.35)$ vs $0.45(0.33-0.55), P<0.001$. The discriminatory power of these markers to distinguish between the BM- patient group and the VM patient group was not studied.

Ray et al compared a group of $18 \mathrm{BM}-$ with a group of 133 non-BM cases. ${ }^{53}$ The most discriminatory threshold value between the two groups for each parameter was defined using ROC curves. It was $1.31 \mathrm{~g} / \mathrm{L}$ for CSF protein concentrations (Se 63\% and Sp 94\% for BM diagnosis), 0.15 for CSF:serum glucose (Se 33\% and Sp 42\%), $22 \mathrm{mg} / \mathrm{L}$ for serum CRP (Se $78 \%$ and $\mathrm{Sp} 74 \%$ ), and $2.13 \mathrm{ng} / \mathrm{mL}$ for serum PCT (Se 87\% and $\mathrm{Sp} 100 \%$ ). The latter was only measured in $44 \%$ of patients. In this study, the most discriminatory parameters were CRP and PCT, while only PCT surpassed clinical judgment.

Viallon et al compared two groups using similar methodology with $35 \mathrm{BM}-$ and $218 \mathrm{VM} .^{21}$ The most discriminatory threshold values were $1.88 \mathrm{~g} / \mathrm{L}$ for the CSF protein concentration (Se 89\% and Sp 93\%), 0.48 for CSF:serum glucose (Se $84 \%$ and $\mathrm{Sp} 89 \%$ ), $37 \mathrm{mg} / \mathrm{L}$ for serum CRP (Se 86\% and Sp $84 \%$ ), $3.8 \mathrm{mmol} / \mathrm{L}$ for CSF lactate (Se 63\% and Sp 94\%), and $0.28 \mathrm{ng} / \mathrm{mL}$ for serum PCT (Se $94 \%$ and Sp 97\%). In this study, the most discriminatory parameters were CSF lactate and serum PCT. The threshold for the latter was $<0.5 \mathrm{ng} / \mathrm{mL}$ in two patients $(>0.9 \mathrm{ng} / \mathrm{mL}$ in all the other cases).

In $\mathrm{BM}$ cases with a noncontributory direct examination of CSF, CSF lactates and serum PCT appeared to retain their discriminatory power, which does not seem to be the case for the other traditionally used markers.

\section{Other markers}

Other CSF markers such as interleukin (IL) (IL-1B, IL-6, and IL-8), tumor necrosis factor alpha, heparin-binding protein, soluble triggering receptor expressed on myeloid cells-1, and other numerous parameters were tested. But these tests are sometimes not performed routinely, or the time taken to obtain a result is incompatible with the therapeutic objectives.

\section{Scores and models}

Several scores and predictive models have been developed for BM diagnosis or differential diagnosis between BM and VM, encompassing CSF or serum clinical and/or cytochemical parameters. ${ }^{23,32,60-73}$ These scores and models have been validated by prospective or retrospective studies. ${ }^{66-72}$ They have demonstrated their ability to correctly differentiate BM from VM, but their use and interpretation are not always easy.

A meta-analysis performed on 4,896 children with suspected meningitis, 1,242 (23\%) of whom had BM, and has studied the diagnostic power of the BM score. ${ }^{73}$ Based on this analysis, sensitivity of $99.3 \%$ and specificity of $62.1 \%$ were highlighted for the BM diagnosis. This score confirmed the existence of a population of patients with a low risk of BM (CSF absolute neutrophil count $<1,000$ cells/ $\mu \mathrm{L}, \mathrm{CSF}$ protein $<0.8 \mathrm{~g} / \mathrm{L}$, and peripheral neutrophil count $<10,000$ cells $/ \mu \mathrm{L}$ [with negative CSF Gram's stain and no acute seizure prior to or during presentation]). However, this score only defines a probability and has not been subjected to prospective testing in terms of antibiotic prescription impact. More recently, Chanavet et al have developed another easy-to-use score. ${ }^{65}$ The variables identified with their cutoff value differed between adults and children, and two scores were constructed. The parameters of the children's model included the peripheral blood leukocyte count (with cutoff value at $15 \mathrm{G} / \mathrm{L}), \mathrm{CSF}$ leukocyte count $(>1,700 / \mathrm{mL}), \mathrm{CSF}$ neutrophil percentage $(>80)$, CSF protein $(>2.3 \mathrm{~g} / \mathrm{L})$, and CSF:blood glucose ratio $(<0.33)$. In children, the peripheral blood leukocyte count was not retained, and the other parameters had different cutoff values (CSF leukocyte count $[>1,800 / \mathrm{mL}]$, CSF neutrophil percentage [ $>80]$, CSF protein $[>1.2 \mathrm{~g} / \mathrm{L}]$, and CSF:blood glucose ratio $[<0.30]$ ). For the BM diagnosis, these scores obtained sensitivity and specificity of $100 \%$ and $85 \%$ in adults and $100 \%$ and $71 \%$ in children. These two models benefited from an external (nonprospective) validation and simulation in accordance with the Monte Carlo method confirming this result. Sensitivity and specificity comparison with other scores provided good reproducibility between them, particularly with the BM score and Boyer's score. ${ }^{61,64}$ However, this scope has not been prospectively tested. 


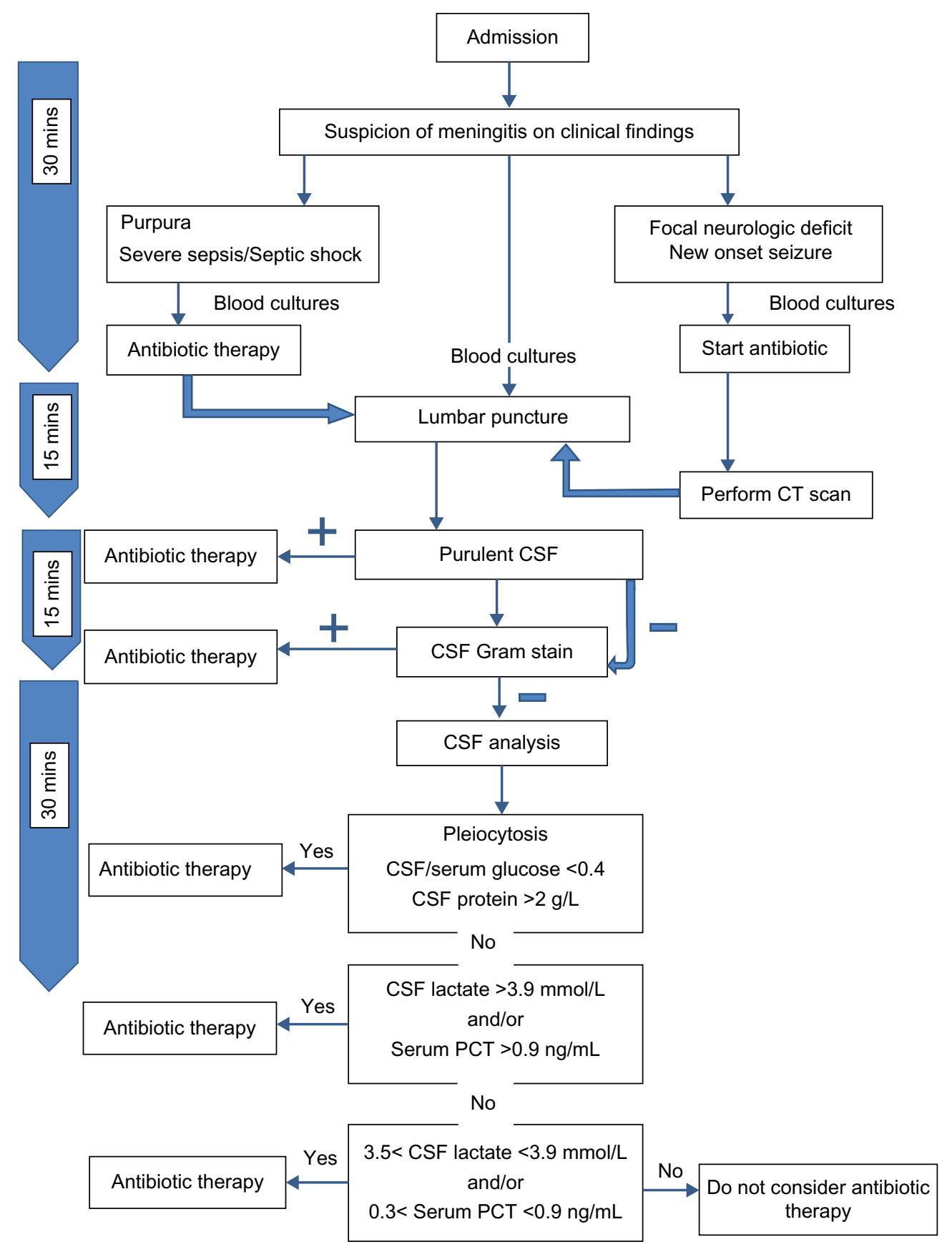

Figure I Making decisions on clinical parameters and cerebrospinal fluid.

Notes: European Federation of Neurological Societies guidelines specified: patents suspected to have raised intracranial pressure on symptoms and signs. Abbreviations: CT, computed tomography; CSF, cerebrospinal fluid; PCT, procalcitonin.

Finally, these scores were not compared to the diagnostic power of certain parameters such as CSF lactates or serum PCT. Neither have they been tested in specific low BM risk populations (ie, low CSF leukocyte count, normal CSF:blood glucose ratio, and negative Gram's stain), which typically represent the difficult diagnosis situations. The authors recommend using this score as a diagnostic aid in so-called difficult situations. Furthermore, none of them used or have been compared to the most relevant markers such as CSF lactate or serum PCT.

\section{Conclusion}

There is no single marker or model for establishing a diagnosis of BM.

The judicious use of the most relevant markers (serum PCT, CSF lactate, and CSF:serum glucose) requires 
knowledge of their threshold values and the limits of their interpretation, particularly in the case of suspected atypical germ-induced BM or prior antibiotherapy (Figure 1).

Clinical reasoning should comprise a multifactorial approach combining clinical parameters and CSF data, with the objective of determining whether or not a first dose of antibiotics is necessary within 30-60 minutes of the patient's admission. The need for a prelumbar puncture CT scan should not delay the administration of antibiotherapy.

Future studies may be necessary to establish the precise role of the most relevant markers in the BM treatment strategy, for example, models vs serum PCT or CSF lactate plus serum PCT.

\section{Disclosure}

The authors report no conflicts of interest in this work.

\section{References}

1. Thigpen MC, Whitney CG, Messonier NE, et al; Emerging Infections Programs. Bacterial meningitis in the United States, 1998-2007. NEngl J Med. 2011;364(21):2016-2025.

2. van de Beek D, de Gans J, Spanjaard L, Weisfelt M, Reitsma JB, Vermeulen M. Clinical features and prognostic factors in adults with bacterial meningitis. $N$ Engl J Med. 2004;351(18):1849-1859.

3. Geiseler PJ, Nelson KE, Levin S, et al. Community-acquired purulent meningitis: a review of 1,316 cases during the antibiotic era, 1954-1976. Rev Infect Dis. 1980;2(5):725-745.

4. Attia J, Hatala R, Cook DJ, Wong JG. Does this patient have acute meningitis. JAMA. 1999;282:175-181.

5. Durand ML, Calderwood SB, Weber DJ, et al. Acute bacterial meningitis in adults. A review of 493 episodes. N Engl J Med. 1993;328(1): $21-28$.

6. Hasbun R, Abrahams J, Jekel J, Quagliarello VJ. Computed tomography of the head before lumbar puncture in adults with suspected meningitis. N Engl J Med. 2001;345(24):1727-1733.

7. Gorse GJ, Thrupp LD, Nudleman KL, et al. Bacterial meningitis in the elderly. Arch Intern Med. 1984;144(8):1603-1606.

8. Cabellos C, Verdaguer R, Olmo M, et al. Community-acquired bacterial meningitis in elderly patients : experience over 30 years. Medicine. 2009;88(2):115-119.

9. Gaschignard J, Levy C, Romain O, et al. Neonatal bacterial meningitis. 444 cases in 7 years. Pediatr Infect Dis J. 2011;30(3):212-217.

10. Kim KS. Acute bacterial meningitis in infants and children. Lancet Infect Dis. 2010;10(1):32-42.

11. Curtis S, Stobart K, Vandermeer B, Simel DL, Klassen T. Clinical features suggestive of meningitis in children: a systematic review of prospective data. Pediatrics. 2010;126(5):952-960.

12. Joffre AR. Lumbar puncture an brain herniation in acute bacterial meningitis. J Intensive Care Med. 2007;22(4):194-207.

13. Proulx N, Fréchette D, Toye B, Chan J, Kravcik S. Delays in the administration of antibiotics are associated with mortality from adult acute bacterial meningitis. QJM. 2005;98(4):291-298.

14. Køster-Rasmussen R, Korshin A, Meyer CN. Antibiotic treatment delay and outcome in acute bacterial meningitis. J Infect. 2008;57(6):449-454.

15. Glimåker M, Johansson B, Grindbor Ö, Bottai M, Lindquist L, Sjölin J. Adult bacterial meningitis: earlier treatment and improved outcome following guideline revision promoting prompt lumbar puncture. Clin Infect Dis. 2015;60(8):1162-1169.
16. Glimåker M, Lindquist L, Sjölin J. Working party of the Swedish infectious disease society for bacterial CNSI. Lumbar puncture in adult bacterial meningitis: time to reconsider guidelines? $B M J$. 2013;346:f361.

17. Brouwer MC, Thwaites GE, Tunkel AR, Van De Beek D. Dilemmas in the diagnosis of acute community-acquired bacterial meningitis. Lancet. 2012;380(9854):1684-1692.

18. Chaudhuri A, Martinez-Martin PM, Kennedy PG, et al; EFNS Task Force. EFNS guideline on the management of community-acquired bacterial meningitis: report of an EFNS task force on acute bacterial meningitis in older children and adults. Eur J Neurol. 2008;15(7):649-659.

19. Oliver WJ, Shope TC, Kuhns LR. Fatal lumbar puncture: Fact versus fiction - an approach to a clinical dilemma. Pediatrics. 2003;112(3 Pt 1): e174-e176.

20. Kanegaye JT, Soliemanzadeh P, Bradley JS. Lumbar puncture in pediatric bacterial meningitis: defining the time interval for recovery of cerebrospinal fluid pathogens after parenteral antibiotic pretreatment. Pediatrics. 2001;108(5):1169-1174.

21. Viallon A, Desseigne N, Marjollet O, et al. Meningitis in adult patients with a negative direct cerebrospinal fluid examination: value of cytochemical markers for differential diagnosis. Crit Care. 2011;15(3):R136.

22. Maxson S, Lewno MJ, Schutze GE. Clinical usefulness of cerebrospinal fluid bacterial antigen studies. $J$ Pediatr. 1994;125(2):235-238.

23. Spanos A, Harrell FE Jr, Durack DT. Differential diagnosis of acute meningitis. An analysis of the predictive value of initial observations. JAMA. 1989;262(19):2700-2707.

24. Coll MT, Uriz MS, Pineda V, et al. Meningococcal meningitis with normal cerebrospinal fluid. J Infect Dis. 1994; 29(3):289-294.

25. Sivakmaran M. Meningococcal meningitis revisited: normocellular CSF. Clin Pediatr. 1994; 36(6):351-355.

26. Donald P, Malan C. Cerebrospinal fluid lactate and lactate deshydrogenase activity in the rapid diagnosis of bacterial meningitis. SAfr Med J. 1986;69(1):39-42.

27. Genton B, Berger JP. Cerebrospinal fluid lactate in 78 cases of adults meningitis. Intensive Care Med. 1990;16(3):196-200.

28. Lindquist L, Linné T, Hansson LO, Kalin M, Axelsson G. Value of cerebrospinal fluid analysis in the differential diagnosis of meningitis: a study in 710 patients with suspected central nervous system infection. Eur J Clin Microbiol Infect Dis. 1988;7(3):374-380.

29. Viallon A, Pouzet V, Zéni F, et al. Rapid differential diagnosis between bacterial and viral meningitis with procalcitonin assay in adults. Presse Med. 2000;29(11):584-588.

30. Sigurdardóttir B, Björnsson OM, Jónsdóttir KE, Erlendsdóttir H, Gudmundsson S. Acute bacterial meningitis in adults. A 20-year overview. Arch Intern Med. 1997;157(4):425-430.

31. Segretti J, Harris AA. Acute baterial meningitis. Infect Dis Clin North Am. 1996. $10: 797-809$.

32. Dubos F, Korczowski B, Aygun DA et al. Serum procalcitonin level and other biological markers to distinguish between bacterial and aseptic meningitis in children. Arch Pediatr Adolesc Med. 2008;162(12):1157-1163.

33. White K, Ostrowski K, Maloney S, Norton R. The utility of cerebrospinal fluid parameters in the early microbiological assessment of meningitis. Diagn Microbiol Infect Dis. 2012;73(1):27-30.

34. Tamune H, Takeya H. Cerebrospinal fluid/blood glucose ratio as an indicator for bacterial meningitis. Am J Emerg Med. 2014;32(3):263-266.

35. Kleine TO, Zwerenz P, Zöfel P, Shiratori K. New and old diagnostic markers of meningitis in cerebrospinal fluid. Brain Res Bull. 2003;61(3):287-297.

36. De Sanctis AG, Killian JA, Garcia T. Lactic acid of spinal fluid in meningitis: practical, diagnosis, and prognostic value. Am J Dis Child. 1933;46:239-249.

37. Guerra R, Tauber MG, Fournier MA, Tureen JH. Lactate and glucose concentrations in brain interstitial fluid, cerebrospinal fluid, and serum during experimental pneumococcal meningitis. $J$ Infect Dis. 1992;166(3):546-550. 
38. Huy NT, Thao NT, Diep DT, Kikuchi M, Zamora J, Hirayama K. Cerebrospinal fluid lactate concentration to distinguish bacterial from aseptic meningitis: a systemic review and meta-analysis. Crit Care. 2010;14(6):R240.

39. Sakushima K, Hayashino Y, Kawaguchi T, Jackson JL, Fukuhara S. Diagnostic accuracy of cerebrospinal fluid lactate for differentiating bacterial meningitis from aseptic meningitis. J Infect. 2011;62(4):255-262.

40. Giulieri S, Chapuis-Taillard C, Jaton K, et al. CSF lactate for accurate diagnosis of community-acquired bacterial meningitis. Eur J Clin Microbiol Infect Dis. 2015;34(10):2049-2055.

41. Hansson LO, Axelsson G, Linné T, Aurelius E, Lindquist L. Serum C-reactive protein in the differential diagnosis of acute meningitis. Scand J Infect Dis. 1993;25(5):625-630.

42. Sutinen J, Sombrero L, Paladin FJE, et al. Etiology of central nervous system infections in the Philippines and the role of serum C-reactive protein in excluding acute bacterial meningitis. Int J Infect Dis. 1999;3(2):88-93.

43. Paradowski M, Lobos M, Krakowiak M, Kubasiewics-Ujma B. Acute phase proteins in serum and cerebrospinal fluid in the course of bacterial meningitis. Clin Biochem. 1995;28(4):459-466.

44. Morales Casado MI, Moreno Alonso F, Juarez Belaunde AL, Heredero Galvez E, Talavera Encinas O, Julian-JimenezA. Ability of procalcitonin to predict bacterial meningitis in the emergency department. Neurologia. 2016;31(1):9-17.

45. Guerdes LU, Jørgensen PE, Nexø E, Wang P. C-reactive protein and bacterial meningitis: a meta-analysis. Scand J Clin Lab Invest. 1998;58(5):383-394.

46. Dandona P, Nix D, Wilson MF, et al. Procalcitonin increase after endotoxin injection in normal subjects. J Clin Endocrinol Metab. 1994;79(6):1605-1608.

47. Assicot M, Gendrel D, Carsin H, Raymond J, Guilbaud J, Bohuon C High serum procalcitonin concentrations in patients with sepsis. Lancet. 1993;341(8844):515-518.

48. Gendrel D, Raymond J, Assicot M, et al. Measurement of procalcitonin levels in children with bacterial or viral meningitis. Clin Infect Dis. 1997;24(6):1240-1242.

49. Viallon A, Zeni F, Lambert C, et al. High sensitivity and specificity of serum procalcitonin levels in adults with bacterial meningitis. Clin Infect Dis. 1999;28(6):1313-1316.

50. Schwarz S, Bertram M, Schwab S, Andrassy K, Hacke W. Serum procalcitonin levels in bacterial and abacterial meningitis. Crit Care Med. 2000;28(6):1828-1832.

51. Hoffmann O, Reuter U, Masuhr F, Holtkamp M, Kassim N, Weber JR. Low sensitivity of serum procalcitonin in bacterial meningitis in adults. Scand J Infect Dis. 2001;33(3):215-218.

52. Jereb M, Muzlovic I, Hojker S, Strle F. Predictive value of serum and cerebrospinal fluid procalcitonin levels for the diagnosis of bacterial meningitis. Infection. 2001;29(4):209-212.

53. Ray P, Badarou-Acossi G, Viallon A, et al. Accuracy of the cerebrospinal fluid results to differentiate bacterial from non bacterial meningitis, in case of negative gram-stained smear. Am J Emerg Med. 2007;25(2):179-184.

54. Onal H, Onal Z, Ozdil M, Alhaj S. A new parameter in the differential diagnosis of bacterial and viral meningitis. Neurosciences. 2008;13(1):91-92.

55. Makoo ZB, Reza H, Hasani A, Makoo RB, Mashrabi O. Diagnostic value of serum and cerebrospinal fluid procalcitonin in differentiation bacterial from aseptic meningitis. Am J Infect Dis. 2010;6(4):93-97.

56. Abdelkader NA, Mahmoud WA, Saber SM. Serum procalcitonin in Egyptian patients with acute meningitis and a negative direct cerebrospinal fluid examination. J Infect Public Health. 2014;7(2):106-113.
57. Konstantinidis T, Cassimos D, Gioka T, et al. Can procalcitonin in cerebrospinal fluid be a diagnostic tool for meningitis? J Clin Lab Anal. 2015;29(3):169-174.

58. Shen HY, Gao W, Cheng JJ, et al. Direct comparison of the diagnostic accuracy between blood and cerebrospinal fluid procalcitonin levels in patients with meningitis. Clin Biochem. 2015;48(16-17):1079-1082.

59. Vikse J, Henry BM, Roy J, Ramakrishnan PK, Tomaszewski KA, Waloch JA. The role of serum procalcitonin in the diagnosis of bacterial meningitis in adults: a systematic review and meta-analysis. Int J Infect Dis. 2015;38:68-76.

60. Oostenbrink R, Moons KG, Donders AR, Grobbe DE, Moll HA. Prediction of bacterial meningitis in children with meningeal signs: reduction of lumbar punctures. Acta Paediatr. 2001;90(6):611-617.

61. Nigrovic LE, Kuppermann N, Malley R. Development and validation of a multivariable predictive model to distinguish bacterial from aseptic meningitis in children in the post-Hemophilus influenzae era. Pediatrics. 2002;110(4):712-719.

62. Hoen B, Viel JF, Paquot C, Gérard A, Canton P. Multivariate approach to differential diagnosis of acute meningitis. Eur J Clin Microbiol. 1995;14(4):267-274.

63. Bonsu BK, Harper MB. Differentiating acute bacterial meningitis from acute viral meningitis among children with cerebrospinal fluid pleocytosis: a multivariable regression model. Pediatr Infect Dis J. 2004;23(6):511-517.

64. Thone J, Bovier-lapierre M, Vercherat M, Boyer P. Bacterial or viral meningitis? Study of a numerical score permitting early orientation in meningitis difficult to diagnose. Pediatrie 1980;35(3):225-236.

65. Chavanet P, Schaller C, Levy C, et al. Performance of a predictive rule to distinguish bacterial and viral meningitis. J Infect. 2007;54(4): 328-336.

66. Oostenbrink R, Moons KG, Derksen-Lubsen AG, Grobbee DE, Moll HA. A diagnostic decision rule for management of children with meningeal signs. Eur J Epidemiol. 2004;19(2):109-116.

67. Oostenbrink R, Moons KG, Twijnstra MJ, Grobbee DE, Moll HA. Children with meningeal signs: predicting who needs empiric antibiotic treatment. Arch Pediatr Adolesc Med. 2002;156(12):1189-1194.

68. Nigrovic LE, Kuppermann N, Maclas CG, et al; Pediatric Emergency Medicine Collaborative Research Committee of the American Academy of Pediatrics. Clinical prediction rule for identifying children with cerebrospinal fluid pleocytosis at very low risk of bacterial meningitis. JAMA. 2007;297(1):52-60.

69. Dubos F, Lamotte B, Bibi-Triki F, et al. Clinical decision rules to distinguish between bacterial and aseptic meningitis. Arch Dis Child. 2006;91(8):647-650.

70. McKinney WP, Heudebert GR, Harper SA, Young MJ, McIntire DD. Validation of a clinical prediction rule for the differential diagnosis of acute meningitis. J Gen Intern Med. 1994;9(1):8-12.

71. Leblebicioglu H, Esen S, Bedir A, Gunaydin M, Saniç A. The validity of Spanos' and Hoen's models for differential diagnosis of meningitis. Eur J Clin Microbiol Infect Dis. 1996;15(3):252-254.

72. Baty V, Viel JF, Schuhmacher H, Jaeger F, Canton P, Hoen B. Prospective validation of a diagnosis model as an aid to therapeutic decision-making in acute meningitis. Eur J Clin Mirobiol Infect Dis. 2000;19(6):422-426.

73. Nigrovic LE, Malley R, Kuppermann N. Meta-analysis of bacterial meningitis score validation studies. Arch Dis Child. 2012; 97:799-805 
Open Access Emergency Medicine

Dovepress

\section{Publish your work in this journal}

Open Access Emergency Medicine is an international, peer-reviewed, open access journal publishing original research, reports, editorials,

Visit http://www.dovepress.com/testimonials.php to read real quotes reviews and commentaries on all aspects of emergency medicine. The manuscript management system is completely online and includes a very quick and fair peer-review system, which is all easy to use. from published authors.

Submit your manuscript here: http://www.dovepress.com/open-access-emergency-medicine-journal 